\title{
Microbiological Characteristics and Mineral Content of Local Smoked cheese produced in Yemen
}

\author{
Habib M. Thabet, Qais A. Nogaim, Tarek A. Alazaze, Yusef Sarhan Alabadli, Saleh Ali Aon \\ Department of Food Science and Technology, Faculty of Agriculture and Veterinary Medicine, IBB University, IBB, Yemen
}

\section{Email address:}

habeeb30@gmail.com (Habib. M. Thabet), qaisnogaim@gmail.com (Qais A. Nogaim.)

\section{To cite this article:}

Habib M Thabet, Qais A. Nogaim, Tareq A. Alazaze, Yusef Sarhan Alabadli, Saleh Ali Aon. Microbiological Characteristics and Mineral Content of Local Smoked Cheese Produced in Yemen. Journal of Food and Nutrition Sciences. Vol. 1, No. 4, 2013 , pp. 65-71.

doi: 10.11648/j.jfns.20130104.16

\begin{abstract}
This study aimed to investigate the microbiological quality and mineral content of smoked cheese collected from different retail markets from Ibb and Taiz areas in Yemen. The microorganisms were determined as follows: Mesophilic bacteria, Proteolytic, Halotolerant, Coliforms, Staphylococcus aureus, Yeast and Mold as well as the presence of Salmonella spp, Escherichia coli. Cheese made in Ibb and Taiz areas had significant differences $(\mathrm{P}<0.05)$ in mesophilic, proteolytic, halotolerant, Staphylococcus aureus microorganisms, yeast and mold. Salmonella spp was not detected. $\mathrm{pH}, \mathrm{NaCl}$, fat and moisture content were also analyzed There was no significant differences for chemical composition except in moisture content. Minerals including $\mathrm{Cd}, \mathrm{Cu}, \mathrm{Fe}, \mathrm{Mn}$ and $\mathrm{Pb}$ were analyzed using atomic absorption spectrometry. The order levels of the metals in the Smoked cheese samples was determined to be $\mathrm{Mn}<\mathrm{Pb}<\mathrm{Cd}<\mathrm{Cu}<\mathrm{Fe}$, with mean concentration 0.47, 0.53, $0.73,1.56$ and $7.84 \mu \mathrm{g} / \mathrm{g}$, respectively. The investigation showed high microorganism counts, high levels of metals and poor quality of Smoked cheese, according to the Yemen Standardization (YSMO: 1556/1998).
\end{abstract}

Keywords: Smoked, Cheese, Mineral levels, Taiz

\section{Introduction}

Smoked cheese is the traditional cheese of Yemen, also called taizzy cheese, the most commonly consumed cheese in the Yemen, taiz located in the southern Yemen. The smoked cheese is produced from mostly raw goats and powder milk in farms or mostly private houses.

The product is considered as a semi-hard cheese with about $40 \%$ moisture content and characterized as a salted cheese with an attractive light brown color imposed by smoking (1). The smoked cheese is popular with consumers and, while large quantities of cheeses are sold immediately after production, its texture is semi-hard or hard and it is sold in disks, at room temperature. The fresh cheese product has a characteristic with a nice brown color all over surface of the cheese and imparted a characteristic aroma.

Most traditional cheeses are usually produced under poor hygienic conditions with different manufacturing technologies that are dependent on the geographical location (2). It has to be noted that there is no standardized processing method for smoked cheese production. Raw milk contaminated with foodborne pathogens and introduced into dairy processing plant constitute a risk to human health if used unpasteurized for the production of some types of cheeses or in case of cross contamination with pathogens (3). The safety of raw milk cheese has been questioned, however, as several large outbreaks of foodborne disease due to consumption of raw milk cheeses have been reported in the past 10 to 20 years $(4,5-6)$.

Cheese produced from raw milk was based on the assumption that pathogenic organisms, even if present initially in the milk or curd, would eventually die in the low $\mathrm{pH}$, low water activity and high salt $(7,8-9,10)$. Humans have been found to serve as contamination source of cheese with pathogenic bacteria like $S$. aureus (11).

Cheese are exposed to different types of contamination during manufacture processing with different kinds of heavy metals such as cadmium, nickel, lead, copper and mercury (12). It causes many health problems such as weakness, heart failure, induced cancer diseases (13) and also affects the kidney. National Oncology Centre (NOC), located in the capital, Sana'a. 2008 reported that 360000 cancer cases in Yemen at present, with 22000 new cases each year and 12000 annual cancer-related deaths. Most of these cases and kidney failures were related to consumption foods and water, which contaminated with minerals. The 
heavy metal content of cheese is variable due to factors such as differences between species, geographical area, characteristics of the manufacturing practices and possible contamination from the equipment during the process (14, 15-16). For cheese samples, $\mathrm{Cd}, \mathrm{Cu}$ and $\mathrm{Pb}$ levels were systematically higher than in milk, suggesting an effect of concentration at the stage of curdling in the cheese process and whey removal (17). Metals such as $\mathrm{Cu}$ and $\mathrm{Fe}$ are essential micronutrients and have a variety of biochemical functions in all living organisms. While $\mathrm{Cu}$ and $\mathrm{Fe}$ are essential, they can be toxic when taken in excess; both toxicity and necessity vary from one element to another (18).

There has been no study carried out on the metals aspects of smoked cheese. The purposes of this study was to determine some of microbiological characteristics and minerals contents of traditional smoked cheese which has sold in local market without refrigerated.

\section{Materials and Methods}

\subsection{Collection of Smoked Cheese Samples}

Twenty six samples were collected from different of public markets of the ( Ibb and Taiz cities) Yemen during January and May 2012. The samples were transported in sterile plastic bags to the laboratory under aseptic and refrigerated conditions. All samples were stored at $4{ }^{\circ} \mathrm{C}$ and processed within $24 \mathrm{~h}$ of collection.

\subsection{Microbiological Characteristic}

Cheese samples were analyzed for microbiological aspects according to standard methods. In general, the samples were obtained from the core or interior portions of the cheese, although small amounts of surface material may have also been incorporated into some of the samples.

Cheese samples of $10 \mathrm{~g}$ were homogenized with $90 \mathrm{ml}$ sterile $0.1 \%$ peptone water with $0.1 \%$ Tween 80 for $2 \mathrm{~min}$, then serial 10 -fold dilutions were prepared and plated in duplicate (19).

(I) Determination of total of mesophilic bacteria and coliform were on plate count agar at $30{ }^{\circ} \mathrm{C}$ for $48 \mathrm{~h}$ and on Violet Red Bile agar at $30{ }^{\circ} \mathrm{C}$ for $24 \mathrm{~h}$, respectively (20). For the determination of Escherichia coli, coliform colony on EC btroth in sterile tubes with Durham's tubes at $44.5^{\circ} \mathrm{C}$ for 24h. The gas formation in Durham's tubes was then assessed as positive (21). (II) Proteolytic microorganisms grown on plate count agar supplemented with skimmed milk reconstructed at $10 \%$ at $30{ }^{\circ} \mathrm{C}$ for $48 \mathrm{~h}$ (22). (III) Halotolerant microorganisms determined on Mannitol Salt agar at $35-37^{\circ} \mathrm{C}$ for $48 \mathrm{~h}$. (V) Staphylococcus aureus counts enumerated on Baird-Parker agar supplemented with egg yolk and potassium tellurite at $35-37^{\circ} \mathrm{C}$ for $48 \mathrm{~h}$ (19).

(IV) Yeast and mold were grown on Potato Dextrose agar acidified with $10 \mathrm{ml} / 1$ of $10 \%$ tartaric acid (23) and the $\mathrm{pH}$ was adjusted to 3.5. Then from each sample $0.1 \mathrm{ml}$ dilutions were deposited on the surface of Potato Dextrose agar. After incubation at $25^{\circ} \mathrm{C}$ for 5 days counts were performed on the plate. (VI) Smoked cheese samples were examined for the presence of Salmonella spp. a sample of 25 g was homogenized with $225 \mathrm{ml}$ of nutrient lactose broth, and incubated at $35-37{ }^{\circ} \mathrm{C}$ for $24 \mathrm{~h}$, then $1 \mathrm{ml}$ of pre-enrichment broth was subcultured in $10 \mathrm{ml}$ of tetrationate broth and another $1 \mathrm{ml}$ in $10 \mathrm{ml}$ of Rappaport-Vassiliadis broth, incubated at $41^{\circ} \mathrm{C}$ for $24 \mathrm{~h}$. Subcultures were streaked onto bismuth-sulfite agar and xylose-lysine-desoxycholate and the plates were incubated at $35-37^{\circ} \mathrm{C}$ for $24-48 \mathrm{~h}(19)$.

\subsection{Chemical Analysis}

The $\mathrm{pH}$ of cheese was measured using a $\mathrm{pH}$ meter with a glass electrode (LabTech, 300-Iindia). Salt and fat content were determined according to IDF methods (24). Moisture content was determined according to (20). Triplicate tests were performed for each analysis.

\subsection{Metal levels Analysis of Smoked Cheese}

$1 \mathrm{~g}$ of smoked cheese samples was ashed. The ashes were digested with $3 \mathrm{ml}$ of nitric acid $\left(\mathrm{HNO}_{3}, 65 \%\right)$ added to 15 $\mathrm{ml}$ of distilled water on the sample and mixed. The residue was filtered through Whatman filter paper and then the sample was diluted to $10 \mathrm{ml}$ with distilled water. Metal concentrations were then determined in acidic samples using flame atomic absorption spectrometry (Nova, 300, Germany), for $\mathrm{Cd}, \mathrm{Cu}, \mathrm{Fe}, \mathrm{Mn}$, and $\mathrm{Pb}$, according to (25, 26).

\subsection{Statistical Analysis}

The results of microbiological and minerals contents are given as means and standard deviations (SD), with 26 being the number of smoked cheese samples. Two times were carried out for each analysis. All the statistical analysis was performed at $95 \%$ level of significance using (SASS 9.1) program.

\section{Results and Discussion}

\subsection{Microbiological Characteristics of Cheese in Different Areas}

Due to increasing interest in traditionally produced raw milk cheeses that makes questions about the safety of these products more important. The aim of this study was to survey the presence of potential pathogen microorganisms and metals contents during the sale of smoked cheese on local markets of Yemen, which has been produced by using raw milk.

The results of some microbiological properties and chemicals analysis of smoked cheese are presented in Tables 1, 2. For all cheese samples, the $\mathrm{pH}$ ranged from 4.0 to 5.5 . The moisture content ranged from 44.6 to $59.7 \%$. The fat and salt content were in the range of 10 to 17 and 3.00 to 7.1 respectively. The comparisons of samples among 
areas showed significant differences $(\mathrm{P}<0.05)$ in the water content in Ibb and Taiz only.

Table 1. The Microbiological accounts of 26 samples of Smoked cheese in different areas $(\log c f u / g)$

\begin{tabular}{lll}
\hline Parameter /Areas & Ibb & Taiz \\
\hline Mesophilic & $7.98 \pm 0.76 * \mathrm{a}$ & $5.08 \pm 0.23 * \mathrm{~b}$ \\
Proteolytic & $4.06 \pm 0.62 * \mathrm{a}$ & $2.66 \pm 0.17 * \mathrm{~b}$ \\
Halotolerant & $6.04 \pm 0.43 * \mathrm{a}$ & $4.72 \pm 0.84 * \mathrm{~b}$ \\
Staphylococcus & $5.83 \pm 0.48 * \mathrm{a}$ & $4.16 \pm 0.61 * \mathrm{~b}$ \\
Coliform & $5.22 \pm 0.71 *$ & $4.04 \pm 0.51 *$ \\
E.coli & $4.91 \pm 0.24 *$ & $3.06 \pm 0.08 *$ \\
Yeast and molds & $4.14 \pm 0.71 * \mathrm{a}$ & $6.12 \pm 0.42 * \mathrm{~b}$ \\
Salmonella spp & nd & nd \\
\hline
\end{tabular}

[ Mean counts $\log \mathrm{cfu} / \mathrm{g} \pm$ standard deviation for smoked cheeses. nd not detected.

Means with different letter superscripts ( $\mathrm{a}$ and $\mathrm{b}$ ) differ significantly of Ibb and Taiz cheese $(P<0.05)$.

Table 2. The Chemical Characteristics of Smoked Cheese Samples.

\begin{tabular}{lllll}
\hline Parameter & Areas & Mean \pm SD & Minimum & Maximum \\
\hline Moisture (\% & Ibb & $51.26 \pm 5.18^{\mathrm{a}}$ & 44.6 & 59.5 \\
w/w) & Taiz & $54.61 \pm 4.48^{\mathrm{b}}$ & 47.0 & 59.7 \\
& Ibb & $4.46 \pm 0.50$ & 4.0 & 5.4 \\
$\mathrm{pH}$ & Taiz & $4.60 \pm 0.51$ & 4.0 & 5.5 \\
& Ibb & $4.40 \pm 1.20$ & 3.0 & 7.1 \\
Salts (\% w/w) & Taiz & $4.20 \pm 0.92$ & 3.6 & 6.5 \\
& Ibb & $14.00 \pm 1.73$ & 11.0 & 17.0 \\
Fat (\%) & Taiz & $13.30 \pm 2.05$ & 10.0 & 17.0 \\
\hline
\end{tabular}

Means with different letter superscripts ( $a$ and $b$ ) differ significantly of Ibb and Taiz cheese $(P<0.05)$.

The difference in microbiological characteristics of cheese between different areas may be attributed to variations in processing environment, handling, raw milk, storage and place of distribution. Furthermore, the milk composition could be influenced by feeds and different lactation stages $(27,28)$.

The total mesophilic bacteria, yeast and mould counts in smoked cheese was significantly different between Ibb and taiz areas (Table 1), but are lower compare to Carra traditional Turkish cheese, which made from raw milk (29). They found the mean counts of aerobic mesophilic bacteria as $1.87 \times 10^{8}$ and yeast and moulds $4.80 \times 10^{7}$, respectively. Similar to our results, (30) found the aerobic mesophilic bacteria was 8.0, 6.7 and $5.9 \mathrm{log} / \mathrm{g}$ in raw goat milk cheeses, treated by high-pressure at different stages of maturation. The number of yeast and molds in our study could be supported by the explanation of (31) that low $\mathrm{pH}$, moisture content and temperature contribute to the growth of yeast. Table 2 shows, smoked cheese has low $\mathrm{pH}$, relatively low moisture content and high salt.

In the smoked cheese 21 out 26 samples $(80.7 \%)$ of ibb and taiz areas were also found to be contaminated with $S$. aureus with mean of 5.83 and $4.16 \mathrm{log} \mathrm{cfu} / \mathrm{g}$ respectively, was always lower than the count of halotolerant, contaminated which probably due to the poor hygienic processing conditions. In the earlier study raw milk was established as the main source of contamination with $S$. aureus for four contaminated final products and food handlers were a potential source of contamination for another final product. Contamination of milk and cheese with $S$. aureus by food handlers was also reported in other studies (11). (32) reported three out of 41 raw milk cheeses in United States, are contaminated with $S$. aureus ranging from $10^{2} \mathrm{cfu} / \mathrm{g}$ to $10^{4} \mathrm{cfu} / \mathrm{g}$. The $S$. aureus counts also lower than that in local Yemen cheese (33). S. aureus numbers in the five samples of cheese made from raw milk should not exceed $10^{3} \mathrm{cfu} / \mathrm{g}$ and the maximum permissible $S$. aureus number in 2 of 5 samples is $10^{4} \mathrm{cfu} / \mathrm{g}$ according to the European Union (34).

Coliform counts in smoked cheese was slightly higher than those found in white turkey cheese and raw milk cheese which were $4.3 \times 10^{3}$ and $2.7 \times 10^{3} \mathrm{cfu} / \mathrm{g}$, respectively $(35,33)$. The high counts of $S$. aureus and coliform in smoked cheese that due to of insufficient hygienic conditions during the manufacturing, selling period and use of raw milk. The ccounts of E.coli. differed between Ibb and Taiz areas with mean 4.91 and $3.06 \mathrm{log}$ $\mathrm{cfu} / \mathrm{g}$ respectively, these differences could be due to the random arrive of E.coli in cheeses, normally by contamination during cheese making. In comparison with Carra cheese the E.coli $3.65 \mathrm{log} \mathrm{cfu} / \mathrm{g}$ was higher than Taiz area, but low than Ibb area (29). The author suggests that may be caused by the higher salt content and low moisture content, which agreement with our results (Table 3). E. coli can be a food safety hazard; therefore, it is very essential to find preventive means for inhibiting growth and survival to avoid contamination of $E$. coli in cheeses.

Proteolytic microorganisms varied significantly between smoked cheese of Ibb and Taiz areas, 7 smoked cheese samples, where their counts were 4.06 and $2.66 \mathrm{log} \mathrm{cfu} / \mathrm{g}$. Fluctuations of proteolytic microorganisms of this study were similar to those observed by (36) in Crottin goat cheese made in different seasons.

Salmonella contaminate raw milk from the farm environment, e.g. faeces. Thus, to avoid raw milk contamination at farm, good farm practices (e.g. animal and waste management, water treatment, good hygienic conditions during milking and mastitis control) are essential to prevent the accumulation, survival, and transmission of pathogens (37).

Salmonella spp. was not detected during this study. Similar to our results Salmonella has not been detected in any of the 4437 samples of fresh, ripened and semi-hard cheeses made from raw, thermized or pasteurized milk that have been analyzed in two studies undertaken in UK during 2004 and 2005 (38). 
Although S. typhimurium was survive in 3 out of several smoked cheese sample storage for difference period of time (34). The statistical analysis of variance showed that areas significantly affected $(\mathrm{P}<0.05)$ the microbial counts of all bacteria, except coliform and E.coli.

\subsection{Minerals Levels}

The research on trace metals in various milk and dairy products has recently gained a remarkable importance. Because, their presence can represent a qualitative parameter for example a content of production procedures, environmental pollution, sanitary conditions, and quality of animal feeding that can affect milk characteristics, cheese properties, and storage and health aspect. For this reason, some trace elements are the actual importance because of their correlation to environmental pollution, and others release from packaging and alloys of material and tools utilized for milking to dairy productions (39). The traditional smoked cheese which has been produced at home or in small scale and sold in the market without packing, result major heavy metals contaminated smoked cheese from the environment pollution. Figure 1 showed that the highest concentration of heavy metals cadmium and lead in Taiz areas compared to Ibb area, that is due to many of industry factory in Taiz and transportation vehicles.

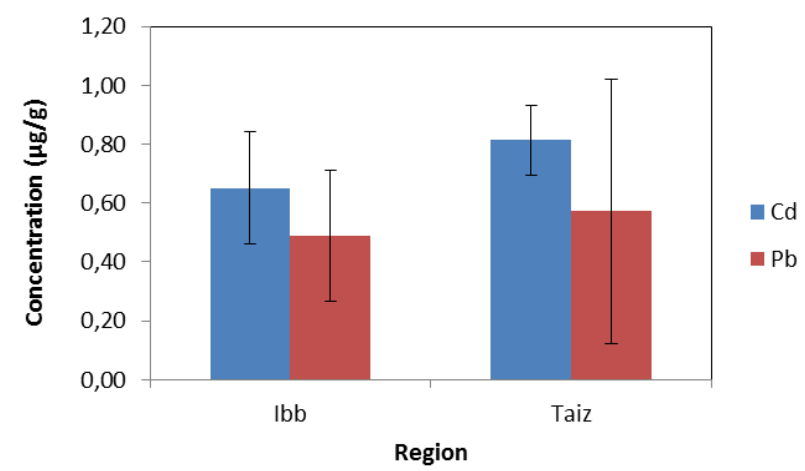

Figure 1. The concentration of heavy metals cadmium and lead in Ibb and Taiz region

The results of minerals metals concentrations were determined on a wet weight basis as $\mu \mathrm{g} / \mathrm{g}$ Table 3 . This research was conducted for the first time in Yemen for the investigation of the concentration of minerals in local cheeses. The concentration levels ( $\mathrm{Fe}, \mathrm{Cd}, \mathrm{Mn}, \mathrm{Cu}$ and $\mathrm{Pb}$ ) measured in the twenty six different of smoked cheese are shown in Table 3.

\subsubsection{Iron}

The iron values of the samples varied from 1.88 to 19.77 $\mu \mathrm{g} / \mathrm{g}$. Our results were close to those of $(16,40)$ for concentration of iron was found in cheese, ranging from $1-14 \mathrm{~g} / \mathrm{kg}$ and $7.68-17.8 \mathrm{ppm}$, respectively. The concentration of iron ranged from 3.9 to $11.9 \mu \mathrm{g} / \mathrm{g}$ of cheese samples were reported by (41).
Table 3 . Lead, Manganese, Copper, Ferrous and Cadmium $(\mu \mathrm{g} / \mathrm{g})$ in samples of smoked cheese collected from Ibb and Taiz areas, Yemen.

\begin{tabular}{|c|c|c|c|c|c|c|}
\hline $\begin{array}{l}\text { No of } \\
\text { samples }\end{array}$ & $\begin{array}{l}\text { Area } \\
\text { s }\end{array}$ & $\begin{array}{l}\text { Cd } \\
\mu \mathrm{g} / \mathrm{g}\end{array}$ & $\mathrm{Fe} \mu \mathrm{g} / \mathrm{g}$ & $\begin{array}{l}\mathrm{Cu} \\
\mu \mathrm{g} / \mathrm{g}\end{array}$ & $\begin{array}{l}\text { Mn } \\
\mu g / g\end{array}$ & $\mathrm{~Pb} \mu \mathrm{g} / \mathrm{g}$ \\
\hline 1 & $\mathrm{Ibb}$ & 0.65 & 3.23 & 5.28 & 0.39 & 0.43 \\
\hline 2 & $\mathrm{Ibb}$ & 0.31 & 9.56 & 1.98 & 0.19 & 0.95 \\
\hline 3 & $\mathrm{Ibb}$ & 0.35 & 3.17 & 6.41 & 0.12 & 0.80 \\
\hline 4 & $\mathrm{Ibb}$ & 0.60 & 9.37 & 1.83 & 0.18 & 0.49 \\
\hline 5 & $\mathrm{Ibb}$ & 0.36 & 5.62 & 5.46 & 1.38 & 0,19 \\
\hline 6 & $\mathrm{Ibb}$ & 0.72 & 2.53 & 1.91 & 0.77 & 0.61 \\
\hline 7 & $\mathrm{Ibb}$ & 0.87 & 4.27 & 0.68 & 0.89 & 0.64 \\
\hline 8 & Ibb & 0.87 & 2.78 & 0.79 & 0.29 & 0.36 \\
\hline 9 & $\mathrm{Ibb}$ & 0.80 & 8.46 & 1.01 & 0.78 & 0.48 \\
\hline 10 & $\mathrm{Ibb}$ & 0.65 & 1.88 & 0.73 & 0.67 & 0.35 \\
\hline 12 & $\mathrm{Ibb}$ & 0.69 & 9.20 & 1.64 & 0.06 & 0.45 \\
\hline 13 & $\mathrm{Ibb}$ & 0.75 & 8.69 & 1.28 & 0.45 & 0.15 \\
\hline 14 & Taiz & 0.82 & 6.42 & 0.94 & 0.61 & 0.45 \\
\hline 15 & Taiz & 0.93 & 4.95 & 0.80 & 0.49 & 0.37 \\
\hline 15 & Taiz & 0.76 & 15.48 & 0.72 & 0.53 & 0.22 \\
\hline 16 & Taiz & 0.69 & 6.87 & 1.19 & 0.50 & 0.49 \\
\hline 17 & Taiz & 0.94 & 14.36 & 0.82 & 0.40 & 1.08 \\
\hline 18 & Taiz & 0.66 & 19.77 & 1.34 & 1.00 & 0.23 \\
\hline 19 & Taiz & 0.79 & 12.12 & 0.49 & 0.28 & 0.21 \\
\hline 20 & Taiz & 0.80 & 7.93 & 0.70 & 0.34 & 1.25 \\
\hline 21 & Taiz & 0.74 & 8.03 & 0.47 & 0.06 & 0.30 \\
\hline 22 & Taiz & 0.89 & 15.50 & 0.81 & 0.13 & 0.13 \\
\hline 23 & Taiz & 0.97 & 8.25 & 0.84 & 0.63 & 1,58 \\
\hline 24 & Taiz & 0.84 & 5.63 & 0.68 & 0.33 & 0.70 \\
\hline 25 & Taiz & 0.63 & 3.25 & 0.95 & 0.45 & 0.35 \\
\hline 26 & Taiz & 0.96 & 6.40 & 0.85 & 0.33 & 0.50 \\
\hline $\begin{array}{l}\text { Mean } \\
\pm \text { SD }\end{array}$ & & $\begin{array}{l}0.73 \pm 0 . \\
18\end{array}$ & $\begin{array}{l}7.84 \pm 4 . \\
55\end{array}$ & $\begin{array}{l}1.56 \pm 1 \\
.59\end{array}$ & $\begin{array}{l}0.47 \pm \\
0.32\end{array}$ & $0.53 \pm 0.35$ \\
\hline
\end{tabular}

The order of the levels of the elements in the samples was determined to be: $\mathrm{Mn}<\mathrm{Pb}<\mathrm{Cd}<\mathrm{Cu}<\mathrm{Fe}$.

\subsubsection{Copper}

Copper is known to be important and toxic for many biological systems. It may enter the food materials from soil through mineralization by crops, food processing or environmental contamination. The essential role of copper in maintaining normal health in both animals and humans has been recognized for many years. Copper concentration ranged from 0.74 to $6.41 \mu \mathrm{g} / \mathrm{g}$, and was lower than those found by (17) which reported an average of 5.35-21.34 $\mu \mathrm{g} / \mathrm{g}$.

\subsubsection{Manganese}

Manganese is a normal component of living things, including both plants and animals, so manganese is present in foods. For nearly all people, food is the main source of manganese. Manganese in the cheese sample ranged from 0.12 to $1.38 \mu \mathrm{g} / \mathrm{g}$, which was larger than the value reported by (42). 


\subsubsection{Cadmium}

Cadmium is a modern an extremely toxic metal, now it is a very important metal with many applications. Because of it's no corrosive properties, its main use in electroplating or galvanizing. $\mathrm{Cd}$ was detected in high concentrations ranging from 0.31 to $0.96 \mu \mathrm{g} / \mathrm{g}$ with the mean values of $0.73 \mu \mathrm{g} / \mathrm{g}$ which was higher than reported in white cheeses by $(43,42)$. The High $\mathrm{Cd}$ content of cheese samples may also be attributed to uncontrolled production and the use of contaminated water in the production process of cheeses due to poor hygiene. Overall cadmium concentrations were comparable to values reported in literature and were below the maximum limit of $500 \mu \mathrm{g} / \mathrm{Kg}$ (44).

\subsubsection{Lead}

Lead is ubiquitous toxic metal and is detectable in practically all phases of the inert environment and in all biological systems, because it is toxic to most living things at high exposures (45). Specific concern varies with the age and circumstances of the host, and the major risk is toxicity to the nervous systems. The principal route of exposure for people in the general population is food, and sources that produce excess exposure and toxic effects are usually environmental. The maximum lead levels was as $1.58 \mu \mathrm{g} / \mathrm{g}$, higher values were reported in Jordan white cheeses by (46) and lower results were reported earlier in turkey white cheese by (47). Most of the minerals in this study, the concentration is higher compared with earlier reports, this is due to minerals transferred to Smoked cheese from water, containers and utensils during manufacturing and selling cheese.

\section{Conclusion}

The present study gives information on raw milk cheese levels of microbiology and heavy metals produced in Yemen. It also provides information on safety and quality of a local and traditional product. The microbiological quality and mineral levels of Smoked cheese sold in the Ibb and Taiz cities non-refrigerated, indicates poor hygienic conditions of cheese products during manufacturing, transport, and marketing, S. aureus numbers and E.coli in samples of cheese should not exceed $10^{3} \mathrm{cfu} / \mathrm{g}$ according to the Yemen Standardization, Metrology and Quality Control Organization (YSMO No: 1556/1998). The marked differences in the number of microorganisms, minerals levels and the values of chemical parameters of Smoked cheese samples appear to result also from different selling practices and insufficient sanitary conditions during the cheese manufacturing. For improving the microbiological and minerals quality of smoked cheese, to reduce the health risk, pasteurized milk should be used instead of raw milk. Clean and high quality materials used during manufacturing and selling processes should be carried out under good hygienic conditions.

\section{Acknowledgments}

The authors are grateful to the IBB University. Republic of Yemen for provided financial assistance during the progress of this work.

\section{References}

[1] Al-Zoreky N. 1998, Isolationof Listeria monocytogenes from Smoked cheese. Journal King Saud University Agriculture Science 2, PP. 163-168.

[2] Freitas A.C. and Malcata f.x.1999, Technological optimisation of Picante cheese using microbiological, chemical and physical criteria. Journal of Food Engineering, 41, pp. 163-170.

[3] Maria K. Marios M. Panagiotis S. and Eleftherios H.D.P.2010, Prevalence and sources of cheese contamination with pathogens at farm and processing levels. Food Control, 21, PP. 805-815.

[4] Ryser E.T. Public health concerns. In, 2001: Marth, E.H., Steele, J.L. (Eds.), Applied Dairy Microbiology, second ed. Marcel Dekker Inc., New York, NY, pp. 397-546.

[5] Vasavada P.C.1988, Pathogenic bacteria in milk e a review. Journal Dairy Science 71, 2809-2816.

[6] West H.G. 2008, Food fears and raw-milk cheese. Appetite $51,25-29$.

[7] Baylis C.L. 2009, Raw milk and raw milk cheeses as vehicles for infection by verocytotoxin-producing Escherichia coli. International. Journal Dairy Technology 62, 293-307.

[8] Donnelly C. 2005, The pasteurization dilemma. In: Kindstedt, P. (Ed.), American Farmstead Cheese: The Complete Guide to Making and Selling Artisan Cheeses. Chelsea Green Publishing Company, White River Junction, Vermont,pp. 173-196.

[9] Johnson M.E. 2001, Cheese products. In: Marth, E.H., Steele, J.L. (Eds.), Applied Dairy Microbiology, second ed. Marcel Dekker Inc., New York, NY, pp. 345-384.

[10] Knight A.J.W.M.R, Todd E.C.D and Bourquin L.D .2008, Listeria in raw mild soft cheese: a case study of risk governance in the United States using the IRGC Framework. In: Renn, O., Walker, K. (Eds.), Global Risk Governance. Springer,Berlin and Dordrecht, pp. 179-220.

[11] Callon C. Gilbert F. B Cremoux R. D and Montel M. C. 2008, Application of variable number of tandem repeat analysis to determine the origin of $S$. aureus contamination from milk to cheese in goat cheese farms. Food Control 19, 143-150.

[12] Ayar A. Durmus-Sert D. and Akın N. 2009, The trace metal levels in milk and dairy products consumed in middle Anatolia, Turkey. Environmental Monitoring Assessment. pp. 152 1-12.

[13] McCally M. 2002, Human health and heavy metals exposure. The Environment and Human Health (Chapter 4).

[14] Feeley R.M. Criner P.E. Murphy E.W. and Toefer E.W.1972, Major mineral elements in dairy products. Journal of dairy Research 61, 505-510. 
[15] Moreno-Rojas R. Amaro-Lopez M. and Zuerera-Cosano G. 1994, Copper, iron and zinc variations in Manchego-type cheese during the traditional cheese-making process. Food Chemistry 49, 67-72.

[16] Yuzbası N. Sezgin E. Yıldırım M. and Yıldırım N. 2003, Survey of lead, cadmium, iron, copper and zinc in Kasar cheese. Food Chemistry 20, 464-469.

[17] Samuel M. Eric L. Frédéric G. Nadia C. and Pierre-Marie B. 2011, Trace metals in raw cows' milk and assessment of transfer to Comté cheese. Food Chemistry 129, 7-12.

[18] Tripathi R.M. Raghunath R. Sastry V.N. and Krishnamoorthy T.M. 1999, Daily intake of heavy metals by infants through milk and milk products. Science total Environment .227, 229-235.

[19] APHA. 2001, In: Frances, P.D., Keith, I. (Eds.), Compendium of Methods for the Microbiological Examination of Foods. APHA, Washington, DC.

[20] Hatzikamari M. Litopoulou-Tzanetaki E. and Tzanetakis N. 1999, Microbiological characteristics of Anevato: a traditional Greek cheese. Journal of Applied Microbiology $87,595-601$.

[21] Marth E.H. 1978, Standard methods for the examination of dairy products. Washington, DC: American Public Health Association.

[22] APHA.1993, In: Marshall, R.T. (Ed.), Standard Methods for the Examination of Dairy Products. APHA, Washington, DC

[23] Kosikowi F.Y. and Mistry V.V. 1997, Cheese and Fermented Milk Foods, vol. 2.Amazon.Com

[24] Determination of salt content-Standard 12B.1988. Brussels: International Dairy Federation.

[25] Gajan R.J. and Larry D. 1972, Determination of lead in fish by atomic absorption spectrophotometry and by polarography. Development of methods. Journal Association of Analytic Chemistry 55 127-130.

[26] Gijs Du. L. Filip M.G. and TackM G. V. 2003, Performance of selected destruction methods for the determination of heavy metals in reed plants. (Phragmites australis) Analytica Chimica Acta 497, 191-198.

[27] Manolopoulou E. Sarantinopolos P. Zoidou E. Aktypis A. Moschopoulou E. Kandarakis I.G. Anifantakis E.M. 2003, Evolution of microbial populations during traditional Feta cheese manufacture and ripening. International Journal Food Microbiology 82, 153-161.

[28] Park Y.W. Kalantari A. and Frank J.F. 2004, Changes in the microflora of commercial soft goat milk cheese during refrigerated and frozenstorage. Small Raiment Research. $53,61-66$.

[29] Osman A. Ozkan A. and Suleyman O. 2005, A survey on the microbiological quality of Carra,a traditional Turkish cheese. Journal of Food Engineering 66, 401-404.

[30] Francisco J.D, José G.C. Ramón C and Rosario R. 2012, Changes in microbiology, proteolysis, texture and sensory characteristics of raw goat milk cheeses treated by high-pressure at different stages of maturation. Food Science and Technology. 48, 268-275.

[31] Beresford T P, Fitzsimons N. A. Brennan N. L. and Cogan T.
M. 2001, Recent advances in cheese microbio. International Dairy Journal, 11, 259-274.

[32] Brooks J.C. Martinez B. Stratton J. Bianchini A. Krokstromb R. and Hutkins R. 2012, Survey of raw milk cheeses for microbiological quality and prevalence of foodborne pathogens. Food Microbiology, 1-5.

[33] Abdulmalek M.A. and Abdulaziz A.A. 2011, Microbiological Changes and Determination of Some Chemical Characteristics for Local Yemeni Cheese. Jordan Journal of Biology Science 4, PP. 93 - 100.

[34] European Council Directive.1992. Laying down the health rules for the production and placing on the market of raw milk, heat-treated milk and milk-based products. European Council Directive 92/46/EEC. Official Journal of the European Communities, L268, 14.9.1992, p. 1.

[35] Seran T. Sahsene A. Cem Sen. Pelin A. 2006, Determination of microbiological contamination sources during Turkish white cheese production. Journal of Food Control 17, 856-861.

[36] Tamagnini L.M. de Sousa G.B. Gonz'alez R.D. and Buddeb C.E. 2006, Microbiological characteristics of Crottin goat cheese made in different seasons. Small Raiment Research $66,175-180$.

[37] Fox L. K. Gershman M. Hancock D.D. and Hutton C.T. 1991, Fomites and reservoirs of Staphylococcus aureus intramammary infections: The effect of milking time hygiene. Cornell Veterinary 81, 183-193.

[38] Little C, L, Rhoades J.R. Sagoo S. K. Harris J. Greenwood, Mithani V. 2008, Microbial quality of retail cheese made from raw, thermised or pasteurized milk in UK. Food Microbiology 25, 304-312.

[39] Coni E. Bocca A. Coppolelli P. Caroli S. Cavallucci C. Trabalza Marinucci M. 1996, Minor and trace element content in sheep and goat milk and dairy products. Food Chemistry. 57, 253-260.

[40] Park Y.W. 2000, Comparison of mineral and cholesterol composition of different commercial goat milk products manufactured in USA. Small Raiment Research 37, $115-124$.

[41] Magda M. A. Madeha N.A. Safaa Y.Q. and Nagwa M. El-Sawi. 2010, Mineral content and microbiological examination of some white cheese in Jeddah, Saudi Arabia during summer 2008. Food and Chemical Toxicology 48, 3031-3034

[42] Dilek B. Yasemin B.K. and Gokhan U. 2012, Determination of some traces metal levels in cheese samples packaged in plastic and tin containers by ICP-OES after dry, wet and microwave digestion. Food and Chemical Toxicology 49, 202-207.

[43] Orak H. Altun and M. Ercag E. 2005, Survey of heavy metals in Turkish white cheese. Italian Journal Food Science $17,95-100$

[44] CE Regulation 2001/466: Off. J Eur Comm. 2001. L 039, 21.

[45] Goyer R.A. Clarkson T.W. 1996, Toxic effects of metals. In: Klaasen, Curtis D. (Ed.),Caserett and Doull's Toxicology: The Basic Science of Poisons, 5th edition.McGraw-Hill, New York. 
[46] Ereifej K.I. and Gharaibeh S.H. 1993, The levels of cadmium, nickel, manganese, lead,zinc, iron, tin, copper and arsenic in the brined canned Jordanian cheese. Z Lebensm Unters Forsch 197, 123-126.
[47] Mendil D. 2006, Mineral and trace metal levels in some cheese collected from Turkey. Food Chemistry, 96, 532-537. 